\title{
Effects of sulphur preservative on phytochemical and antioxidant capacity of peels of mango cultivars (Mangifera indica L.) produced in South Africa
}

\author{
Mudau Fhatuwani Nixwell ${ }^{1 *}$, Mabusela Johanna ${ }^{2}$ and Wonder Ngezimana ${ }^{1}$ \\ ${ }^{1}$ Department of Agriculture, Animal Health and Human Ecology, College of Agriculture and Environmental Sciences, \\ University of South Africa, Private Bag X6 Johannesburg, Florida, South Africa. \\ ${ }^{2}$ Department of Soil Science, Plant Production and Agricultural Engineering, University of Limpopo, Private Bag X1106, \\ Sovenga, 0727, South Africa.
}

Accepted 23 September, 2013

\begin{abstract}
Fruits have abundant phytochemicals that contribute as bioactive molecules with ability to lower incidence of diseases. Mangoes are rich in polyphenols and antioxidants. In this study, peels of six selected mango cultivars (Tommy Atkins, Peach, Saber, Sunshine, Keitt and Vhavenda) were treated with sulphur dioxide solutions $(0,10,20,50,100,150,200,250$ and $300 \mathrm{ppm})$ as preservative of phytochemicals and antioxidants capacity. Regardless of cultivar, sulphur concentration had effect on composition of polyphenols and antioxidant capacity of mango peels, reaching a plateau at $50 \mathrm{ppm}$. Vhavenda cultivar has significantly highest polyphenols and antioxidant capacity than the other cultivars evaluated. This study reveals that mango peels are a prospective source of natural antioxidants as they constitute significantly higher total antioxidant capacity and phenolic content.
\end{abstract}

Key words: Antioxidants, mango cultivars, peels, phytochemicals, sulphur.

\section{INTRODUCTION}

Phytochemicals are compounds that act as free radical scavengers to help eliminate the highly charged oxygen molecules that are byproducts of metabolized oxygen (Khalid, 2007), and are believed to offer various health benefits (Van Duyn and Pivonka, 2000; Min et al., 2013). Antioxidants are substances that can prevent or delay the oxidative damage of lipids, proteins and nucleic acids by reactive oxygen species (ROS), which include free radicals such as hydroxyl, peroxyl and non-radicals such as hydrogen peroxides (Saikat et al., 2010). According to
Pietta (2000), phenolic antioxidants are thought to neutralize ROS before they can cause damage.

The most of the abundant antioxidants in fruits are polyphenols, vitamin $\mathrm{C}, \mathrm{A}$ and $\mathrm{E}$ and carotenoids to a lesser extent in some fruits (Lim et al., 2007). According to Fleuriet and Macheix (2003), most of these polyphenols are flavonoids and are present in the form of ester and glycoside in fruits. Flavonoids commonly found in fruits and vegetables have been linked to reduced risk of mortality from the coronary heart diseases (Wang et

${ }^{*}$ Corresponding author. E-mail: mudaufn@unisa.ac.za. Tel: +27 114713231.

Abbreviations: ROS, Reactive oxygen species; TPC, total polyphenol content; ABTS, 2,2-azino-bis (3-ethylbenzthiazoline-6sulfonic acid; TAC, total antioxidant activity. 
al., 2011).

Phenolic compounds are plant secondary metabolites that are biosynthesized through the shikimic acid pathway (Tomas-Baraeran and Espin, 2001). Phenolic compounds are associated with the health benefits deriving from consuming high levels of fruits (Parr and Bolwell, 2000; Aberoumand, 2012). Mango is regarded as a valuable source of phytochemical compounds (Kim et al., 2007; Ashoush and Gadallah, 2011; Mudau et al., 2013); among these compounds, polyphenolics are widely distributed secondary metabolites and the predominant antioxidants present. Several studies have reported phenolic compounds in mango flesh and peels, including various flavonoids, xathones, phenolic acids and gallotannins (Schieber et al., 2000; Berardini et al., 2005) and variability of these compounds have been observed in different mango cultivars (Souza et al., 2011; Taing et al., 2012).

Mangoes are seasonal fruits with limited shelf-life with fruit quality dropping off rapidly once fully ripe. Mango fruits are processed for various products (Loelillet, 1994) and by-products such as peels and kernels are generated (Ashoush and Gadallah, 2011). These by-products are rich sources of natural bioactive compounds which play an important role in prevention of diseases (Ashoush and Gadallah, 2011).

Studies have been conducted on the utilization of mango kernels as a source of fat (Arogba, 2002), natural antioxidants (Kaur, 2004), starch (Moharram and Moustafa, 1982), flour (Puravankara et al., 2000) and feed (Ravindran and Sivakanesan, 1996) but studies on peels are scarce (Berardini et al., 2005). Most of the studies on the exploitation of mango peels dealt with their use as a source of pectin, which is considered a high quality dietary fiber (Beerh et al., 1976; Srirangarajan and Shrikhande, 1976; Tandon et al., 1991; Pedroza-Islas and Aguilar-Esperanza, 1994; Tandon and Garg, 1999).

The mango peels have been reported to a good source of dietary fiber containing high amount of extractable polyphenolics (Larrauri et al., 1996). According to Ojokoh (2007), mango peel fibre is a good source of dietary fiber and its chemical composition may be compared to citrus fibre. Mango peels also demonstrated higher values of anticancer properties because of polyphenolic extracts (Noratto, 2010) and glucose retardation (Reyers and Vega, 1988). Chemical in peels of certain mango cultivars have also been shown to prevent the formation of fat cells through disrupting adipogenesis (Taing et al., 2012) which is the key in development of obesity (Min et al., 2013).

The use of sulphur solution as a preservative in dried mango has become a commercial drying standard for the industry in South Africa with limited studies evaluating the phytochemical and antioxidant capacity of peels of mango cultivars. As a result, data that describe the use of preservatives in mango byproducts is lacking. Therefore, the objective of this study was to determine the effect of sulphur concentration on polyphenol content and total antioxidant capacity of mango peels for potential usefulness as a preservative.

\section{MATERIALS AND METHODS}

\section{Location}

The experiment was conducted at Agro-food Laboratory, University of Limpopo. The ripe fruits of mango cultivars inter alia; Tommy Atkins, Peach, Saber, Sunshine and Keitt were randomly collected from a commercial orchard in Hoedspruit. Vhavenda cultivar was collected from another commercial orchard in Vhembe District $\left(23^{\circ} \mathrm{N} 50^{\prime} \mathrm{E}, 30^{\circ} \mathrm{S} 17^{\prime} \mathrm{E}\right)$; alt $610 \mathrm{~m}$; subtropical-type climate (that is, summer rainfall and cold, dry winter) of Limpopo Province, South Africa.

\section{Plant materials}

Fresh, healthy and disease free fruits from six selected cultivars were washed and manually peeled. The peels were soaked in a sodium metabisulfite solution (BASF chemical company, Germany). Nine different concentrations of $\mathrm{SO}_{2}$ (in $3 \mathrm{~L}$ of water) were used. Treatment concentrations were 0, 10, 20, 50, 100, 150, 200, 250 and $300 \mathrm{ppm}$. Mango peels from the six cultivars were soaked for 5 min in the solution, and then immediately dried in a hot air oven at $58^{\circ} \mathrm{C}$ for $28 \mathrm{~h}$. Samples of dried peels were stored at $-30^{\circ} \mathrm{C}$ until their analysis.

\section{Sample preparations (extraction)}

For the analysis, $10 \mathrm{~g}$ dried fruit peel samples were weighed and transferred to a waring commercial blender (Instrulab, Johannesburg, South Africa) containing $100 \mathrm{ml}$ of methanol, and then blended at a high speed for 2 min (stopping occasionally to avoid accumulation of fumes). The mixture was removed and let stand in the beaker to achieve separation. After 6-8 min, the supernatant was collected, centrifuged at $12000 \times \mathrm{g}$ for $10 \mathrm{~min}$ and stored. The residues were blended again with $50 \mathrm{ml}$ methanol, supernatant decanted as above, combined with the first one, filtered with MN-615 (240 mm) filter papers (Bethlehem, USA) and stored at $-4^{\circ} \mathrm{C}$ until analysis.

\section{Determination of total phenolics content}

Total polyphenol content (TPC) for fruit peel samples was determined using Waterman and Mole method (1994). In this method, $50 \mathrm{ml}$ volumetric flasks were used, each containing $10 \mathrm{ml}$ of water. Ten (10) $\mathrm{ml}$ of water, $0.5 \mathrm{ml}$ of the sample extracts were added, as well as $2.5 \mathrm{ml}$ of the Folin-Ciocalteau's reagent. Within 2$8 \mathrm{~min}, 7.5 \mathrm{ml}$ of sodium carbonate was added and the flasks were filled with water to $50 \mathrm{ml}$ of volumetric flask mark. The flasks were swirled and allowed to stand for $2 \mathrm{~h}$ in the dark. The absorbance was measured at $760 \mathrm{~nm}$ using Genesis 20 Spectrophotometer (Thermo Electron Corporation, Madison, USA). Data were calculated using a pre-prepared gallic acid calibration curve. A stock solution was prepared by dissolving $0.1 \mathrm{~g}$ gallic acid in $100 \mathrm{ml}$ methanol. Results were expressed as milligrams of gallic acid per $100 \mathrm{ml}$ of sample extracts.

\section{Determination of total antioxidant activity}

The 2,2-azino-bis (3-ethylbenzthiazoline-6-sulfonic acid (ABTS) 
Table 1. Total antioxidant activity value and polyphenols content of dried mango peels treated with sulphur (different concentrations).

\begin{tabular}{|c|c|c|c|c|c|c|c|c|c|c|c|c|c|c|c|c|c|c|c|c|c|c|c|c|}
\hline \multirow{2}{*}{$\begin{array}{c}\text { Sulphur } \\
\text { concentration } \\
\text { (ppm) }\end{array}$} & \multicolumn{4}{|c|}{ Saber } & \multicolumn{4}{|c|}{ Peach } & \multicolumn{4}{|c|}{ Keitt } & \multicolumn{4}{|c|}{ Tommy Atkins } & \multicolumn{4}{|c|}{ Vhavenda } & \multicolumn{4}{|c|}{ Sunshine } \\
\hline & AA & $\begin{array}{l}\text { Std } \\
\text { err }\end{array}$ & TP & $\begin{array}{l}\text { Std } \\
\text { err }\end{array}$ & AA & $\begin{array}{l}\text { Std } \\
\text { err }\end{array}$ & TP & $\begin{array}{l}\text { Std } \\
\text { err }\end{array}$ & AA & $\begin{array}{l}\text { Std } \\
\text { err }\end{array}$ & TP & $\begin{array}{l}\text { Std } \\
\text { err }\end{array}$ & AA & $\begin{array}{l}\text { Std } \\
\text { err }\end{array}$ & TP & $\begin{array}{l}\text { Std } \\
\text { err }\end{array}$ & AA & $\begin{array}{l}\text { Std } \\
\text { err }\end{array}$ & TP & $\begin{array}{l}\text { Std } \\
\text { err }\end{array}$ & AA & $\begin{array}{l}\text { Std } \\
\text { err }\end{array}$ & TP & $\begin{array}{l}\text { Std } \\
\text { err }\end{array}$ \\
\hline 0 & $393.9^{b}$ & \pm 0.2 & $2.0^{b}$ & \pm 0.1 & $392.7^{b}$ & \pm 0.2 & $1.9^{b}$ & \pm 0.1 & $382.7^{b}$ & \pm 0.2 & $1.9^{b}$ & \pm 0.1 & $372.8^{b}$ & \pm 0.2 & $1.7^{\mathrm{b}}$ & \pm 0.1 & $393.7^{b}$ & \pm 0.2 & $1.9^{b}$ & \pm 0.1 & $382.7^{b}$ & \pm 0.2 & $1.9^{b}$ & \pm 0.1 \\
\hline 10 & $409.9^{b}$ & \pm 0.3 & $2.1^{\mathrm{b}}$ & \pm 0.1 & $409.6^{b}$ & \pm 0.2 & $2.2^{b}$ & \pm 0.1 & $409.6^{b}$ & \pm 0.2 & $2.3^{\mathrm{b}}$ & \pm 0.1 & $419.3^{b}$ & \pm 0.2 & $2.3^{b}$ & \pm 0.1 & $429.9^{b}$ & \pm 0.3 & $2.3^{b}$ & \pm 0.1 & $411.6^{\mathrm{b}}$ & \pm 0.3 & $2.3^{\mathrm{b}}$ & \pm 0.1 \\
\hline 20 & $436.6^{b}$ & \pm 0.2 & $2.3^{\mathrm{b}}$ & \pm 0.1 & $435.6^{b}$ & \pm 0.2 & $2.3^{\mathrm{b}}$ & \pm 0.1 & $435.6^{b}$ & \pm 0.2 & $2.4^{\mathrm{b}}$ & \pm 0.1 & $435.5^{\mathrm{b}}$ & \pm 0.2 & $2.5^{\mathrm{b}}$ & \pm 0.1 & $446.6^{\mathrm{b}}$ & \pm 0.2 & $2.5^{\mathrm{b}}$ & \pm 0.1 & $425.6^{b}$ & \pm 0.2 & $2.4^{\mathrm{b}}$ & \pm 0.1 \\
\hline 50 & $465.9^{\mathrm{a}}$ & \pm 0.2 & $3.2^{\mathrm{a}}$ & \pm 0.1 & $467.3^{\mathrm{a}}$ & \pm 0.2 & $3.3^{\mathrm{a}}$ & \pm 0.1 & $457.3^{\mathrm{a}}$ & \pm 0.2 & $3.4^{\mathrm{a}}$ & \pm 0.1 & $467.1^{\mathrm{a}}$ & \pm 0.2 & $3.7^{\mathrm{a}}$ & \pm 0.1 & $475.9^{\mathrm{a}}$ & \pm 0.2 & $3.8^{\mathrm{a}}$ & \pm 0.1 & $487.3^{\mathrm{a}}$ & \pm 0.2 & $3.4^{\mathrm{a}}$ & \pm 0.1 \\
\hline 100 & $416.5^{\mathrm{b}}$ & \pm 0.2 & $2.3^{\mathrm{b}}$ & \pm 0.1 & $416.3^{b}$ & \pm 0.2 & $2.4^{\mathrm{b}}$ & \pm 0.1 & $426.3^{b}$ & \pm 0.2 & $2.2^{\mathrm{b}}$ & \pm 0.1 & $446.3^{b}$ & \pm 0.2 & $2.4^{\mathrm{b}}$ & \pm 0.1 & $426.5^{b}$ & \pm 0.2 & $2.5^{\mathrm{b}}$ & \pm 0.1 & $426.3^{b}$ & \pm 0.2 & $2.2^{b}$ & \pm 0.1 \\
\hline 150 & $408.9^{b}$ & \pm 0.2 & $2.5^{\mathrm{b}}$ & \pm 0.1 & $410.5^{b}$ & \pm 0.2 & $2.5^{\mathrm{b}}$ & \pm 0.1 & $420.5^{b}$ & \pm 0.2 & $2.3^{\mathrm{b}}$ & \pm 0.1 & $430.6^{b}$ & \pm 0.2 & 2.5 & \pm 0.1 & $418.9^{b}$ & \pm 0.2 & $2.5^{\mathrm{b}}$ & \pm 0.1 & $420.5^{b}$ & \pm 0.2 & $2.3^{\mathrm{b}}$ & \pm 0.1 \\
\hline 200 & $409.4^{\mathrm{b}}$ & \pm 0.2 & $2.2^{\mathrm{b}}$ & \pm 0.1 & $410.2^{\mathrm{b}}$ & \pm 0.2 & $2.3^{\mathrm{b}}$ & \pm 0.1 & $420.2^{b}$ & \pm 0.2 & $2.2^{\mathrm{b}}$ & \pm 0.1 & $420.1^{\mathrm{b}}$ & \pm 0.2 & $2.2^{\mathrm{b}}$ & \pm 0.1 & $419.4^{\mathrm{b}}$ & \pm 0.2 & $2.4^{\mathrm{b}}$ & \pm 0.1 & $410.2^{b}$ & \pm 0.2 & $2.3^{\mathrm{b}}$ & \pm 0.1 \\
\hline 250 & $398.2^{b}$ & \pm 0.3 & $2.4^{\mathrm{b}}$ & \pm 0.1 & $405.3^{b}$ & \pm 0.3 & $2.3^{b}$ & \pm 0.1 & $425.3^{b}$ & \pm 0.3 & $2.2^{\mathrm{b}}$ & \pm 0.1 & $415.3^{b}$ & \pm 0.3 & $2.3^{b}$ & \pm 0.1 & $400.2^{b}$ & \pm 0.3 & $2.4^{\mathrm{b}}$ & \pm 0.1 & $425.3^{b}$ & \pm 0.3 & $2.3^{b}$ & \pm 0.1 \\
\hline 300 & $384.9^{\mathrm{b}}$ & \pm 0.2 & $2.7^{\mathrm{b}}$ & \pm 0.1 & $405.1^{\mathrm{b}}$ & \pm 0.2 & $2.6^{\mathrm{b}}$ & \pm 0.1 & $395.1^{\mathrm{b}}$ & \pm 0.2 & $2.1^{\mathrm{b}}$ & \pm 0.1 & $395.3^{\mathrm{b}}$ & \pm 0.2 & $2.1^{\mathrm{b}}$ & \pm 0.1 & $394.9^{\mathrm{b}}$ & \pm 0.2 & $2.2^{\mathrm{b}}$ & \pm 0.1 & $415.1^{\mathrm{b}}$ & \pm 0.2 & $2.2^{b}$ & \pm 0.1 \\
\hline
\end{tabular}

AA, Total antioxidant activity $(\mu \mathrm{mol} / \mathrm{g})$; TP, total polyphenol content $(\mathrm{mg}$ of gallic acid/100 $\mathrm{mg})$. Means with different superscripts along the same column are significantly different $(\mathrm{P}<0.01)$.

assay was used to measure the total antioxidant activity (TAC) of the mango peel extracts. $8 \mathrm{mM}$ ABTS and $3 \mathrm{mM}$ potassium persulfate $\left(\mathrm{K}_{2} \mathrm{~S}_{2} \mathrm{O}_{8}\right)$ were dissolved in $25 \mathrm{ml}$ distilled water each, and then the equal volumes of the two were mixed. The reaction mixture was left to stand at room temperature overnight (12-16 $\mathrm{h}$ ) in the dark before usage.

The resultant intensely coloured ABTS (mother solution) was diluted with phosphate buffered $(\mathrm{pH} 7.4)$ solution to make a working solution. The assay was first carried out on Trolox, the water-soluble a-tocopherol (vitamin E) analogue, which served as standard. Working solution $(2900 \mu \mathrm{l})$ was added to $100 \mu \mathrm{l}$ serial Trolox dilutions, swirled and left to react for $15 \mathrm{~min}$

For sample analysis, dilutions were made by adding $1 \mathrm{ml}$ of the sample extract to $4 \mathrm{ml}$ of the solvent (methanol), and then $2900 \mu \mathrm{l}$ of the working solution was added to $100 \mu \mathrm{l}$ sample extracts, swirled and left to react for $30 \mathrm{~min}$ Absorbance was measured at $734 \mathrm{~nm}$ using Genesis 20 Spectrophotometer (Thermo Electron Corporation, Madison, USA). The assay was performed by triplicates and data were calculated using a Trolox calibration/standard curve. Fresh ABTS solution was prepared everyday due to self-degradation of the radical. The results were expressed as $\mu \mathrm{mol}$ Trolox equivalents (TEAC)

\section{Statistical analysis}

All data were reported as mean \pm standard error of three replicates. Analyses of variance (ANOVA) were performed on data using the General linear model (GLM) procedure of SAS version 8.0 (SAS Institute Inc., 1999). Differences at $\mathrm{P}<0.05$ were considered significant. Treatment means found were separated using Duncan's Multiple Range Test (DMRT).

\section{RESULTS}

\section{Total phenolics composition of mango peels}

The secondary metabolites composition of dried mango peels treated with sulphur at differen concentrations showed that the total polyphenolic content at low concentrations (0,10 and $20 \mathrm{ppm})$ was similar (Table 1). However, at $50 \mathrm{ppm}$ of concentrations, the composition of polyphenols was significantly different to the low and high concentrations tested $(P<0.01)$ (Table 1). The trend was shown in all six cultivars evaluated.

There were differences in the polyphenols on the different mango cultivars ranging from 2.3 $\mathrm{mg} / 100 \mathrm{mg}$ of Keitt mango peels to $2.5 \mathrm{mg}$ of gallic acid/100 mg of Vhavenda mango peels (Table 2). The composition of polyphenols in Vhavenda mango peels was greater than that of the other five cultivars $(P<0.01)$ (Table 2$)$ whilst polyphenolic content of Peach, Saber, Tommy Atkins and Sunshine were significantly the same $(\mathrm{P}<0.01)$.

\section{Total antioxidant capacity of mango peels}

The total antioxidant capacity of dried mango peels treated with sulphur at different concentrations showed that the antioxidant activity at low concentrations $(0,10$ and $20 \mathrm{ppm})$ was similar (Table 1), with the same trend shown in all mango cultivars. However, at $50 \mathrm{ppm}$ of concentrations, the antioxidants activity was significantly different to the low and high concentrations tested $(P<0.01)$ (Table 1). At high concentrations (100,150, 200, 250 and 300 ppm), total antioxidants activity values were similar to the low concentrations (Table 1). There were no significant differences in the total antioxidant activity observed on the different mango cultivars ranging, with values ranging from $413.9 \mu \mathrm{mol} / \mathrm{g}$ of Saber mango peels to $422.9 \mu \mathrm{mol} / \mathrm{g}$ of Vhavenda mango peels (Table 2). 
Table 2. Total antioxidant activity value and polyphenols content of dried mango peels (different cultivars).

\begin{tabular}{|c|c|c|c|c|}
\hline Mango cultivar & $\begin{array}{c}\text { Total antioxidants activity } \\
(\mu \mathrm{mol} / \mathrm{g})\end{array}$ & Standard error & $\begin{array}{l}\text { Total polyphenols content } \\
\text { (mg of gallic acid } / 100 \mathrm{mg} \text { ) }\end{array}$ & Standard error \\
\hline Saber & $413.9^{a}$ & 0.3 & $2.4^{\mathrm{b}}$ & 0.2 \\
\hline Peach & $417.0^{\mathrm{a}}$ & 0.3 & $2.4^{\mathrm{b}}$ & 0.2 \\
\hline Keitt & $419.2^{a}$ & 0.3 & $2.3^{\mathrm{c}}$ & 0.2 \\
\hline Tommy Atkins & $422.5^{\mathrm{a}}$ & 0.3 & $2.4^{\mathrm{b}}$ & 0.3 \\
\hline Vhavenda & $422.9^{\mathrm{a}}$ & 0.3 & $2.5^{\mathrm{a}}$ & 0.1 \\
\hline Sunshine & $422.7^{\mathrm{a}}$ & 0.3 & $2.4^{\mathrm{bc}}$ & 0.2 \\
\hline
\end{tabular}

Means with different superscripts along the same column are significantly different $(P<0.01)$.

\section{DISCUSSION}

Our results demonstrate that dipping mango peels in 50 ppm of $\mathrm{SO}_{2}$ solution was effective in maintaining their bioactive compounds. In this way, previously it was demonstrated that the same concentration can effectively preserve dried mango flesh with maximum proximate composition attained at this level, and the pretreatment of most fruits prior to drying as it enhances inactivation of pathogenic bacteria during dehydration (Mudau et al., 2013; DiPersio et al., 2006). Besides reducing the pathogenic bacteria, treatment in preservatives also maintains the colour of dried fruit products (Davidek et al., 1990) increasing their marketability. Simple pretreatment methods prior to drying of mango slices also lead to significant retention of $\beta$-carotene of which it has high amount of vitamin $A$ and antioxidative capacity (Muoki et al., 2009; Mercandate and Rodriguez-Amaya, 1998).

We found that mango peels possess high contents of the secondary metabolites than the flesh in this work. Similar results were reported by other authors, who found that mango peels containing high levels of polyphenols and dietary fiber (Larrauri et al., 1996; Kim et al., 2010). Also, it was reported that apple peels had higher antioxidant activities than the edible portion of the fruit (Wolfe et al., 2003).

In a recent study reported, it was suggested that mango peel extracts can inhibit adipogenesis likely due to higher concentrations and types of polyphenols in the peel extracts when they are compared with flesh extracts (Taing et al., 2012). For the same cultivars evaluated in this study, there are significantly more bioactive compounds in peels than the flesh (Mudau et al., 2013). Other studies have also shown the content of total polyphenol and antioxidant activities being higher in the peel than the pulp at any stage of mango fruit development (Lakshminarayana et al., 1979; Reyers and Vega, 1988; Ueda et al., 2000; Ajila et al., 2007) and several extraction techniques have been investigated for utilisation of these bioactive compounds (Ashoush and Gadallah, 2011; Palmeira et al., 2012, Meneses et al., 2013).

The variation in polyphenol content of peels of these cultivars as seen in this study may be associated to genetic factors (Mercandate and Rodriguez-Amaya, 1998) and also factors such as soil conditions (Rodríguez Pleguezuelo et al., 2012) and phytosanitary status (Tahir et al., 2002). This variability in polyphenol and antioxidant content has also been observed on mango flesh with causes extended to cultivar (Mercandate and RodriguezAmaya, 1998; Othman and Mbogo, 2009), cultivation practice (Hofman et al., 1995), climatic conditions (Léchaudel and Joas, 2006), ripeness at harvest (Jacobi et al., 1995; Lalel et al., 2003), and even postharvest storage conditions of the fruit (Hofman et al., 1997; Nunes et al., 2007).

Genetic variability in mango cultivars can ultimately lead to differences in carotenoids (Mitra, 1997) and anthocyanin (Lizada, 1991) content. Souza et al. (2011) reported that certain Brazilian mango cultivars have genomic similarities of as little as $7 \%$ showing a significant genetic diversity that could contribute to phytochemical differences between mango fruit cultivars. These phytochemical different cultivars offer potential in diverse uses, including in obese individuals.

In a study done by Taing et al. (2012), where mango peel extracts were reported to be more effective at inhibiting adipo-genesis in 3T3-L1 pre-adipocytes, it was further found that the degree of inhibition was cultivardependent. This difference in activity could be due to genetic variability between mango cultivars resulting in different types or relative amounts of phytochemicals (Taing et al., 2013).

\section{Conclusion}

From this work, we conclude that the natural bioactive compounds can effectively accumulate if mango peels are preserved at $50 \mathrm{ppm}$ of $\mathrm{SO}_{2}$ solutions in all cultivars evaluated. Also, from all cultivars studied in this work; Vhavenda has highest values of total polyphenols (2.5 $\mathrm{mg} / 100 \mathrm{mg}$ ) and antioxidants (422.9 $\mu \mathrm{mol} / \mathrm{g})$; and their peels could be used as a source of natural antioxidants. In general, mango peels with high total antioxidants activity showed the highest polyphenolic contents. 


\section{REFERENCES}

Aberoumand A (2012). Screening of phytochemical compounds and toxic proteinaceous protease inhibitor in some lesser-known food based plants and their effects and potential applications in food. Inter J. Food Sci. Nutr. Eng. 3:16-20.

Ajila CM, Naidu KA, Bhat SG, Prasada Rao USJ (2007). Bioactive compounds and antioxidant potential of mango peel extracts. Food Chem. 105:982-988.

Arogba SS (2002). Mango seed kernel: Chromatographic analysis of the tannin, and stability study of the associated polyphenol oxidase activity. J. Food Compos. Anal. 13:149-156.

Ashoush IS, Gadallah MGE (2011). Utilization of mango peels and seed kernels powders as sources of phytochemicals in biscuit. World $\mathrm{J}$. Dairy \& Food Sci. 6:35-42.

Beerh OP, Raghuramaiah B, Krishnamurthy GV (1976). Utilization of mango wastes: peel as a source of pectin. J. Food Sci. Tech. 13:9697.

Berardini N, Knodler M, Schieber A, Carle R (2005). Utilization of mango peels as a source of pectin and polyphenolics. Innov. Food Sci. Emerging Tech. 6:442-452.

Davidek J, Velisek J, Pokorny (1990). Chemical changes during fruit processing. Elsevier Science. Amsterdam. Netherlands. Pp. 230-310.

DiPersio PA, Kendall PA, Sofos JN (2006). Sensory evaluation of home dried fruit prepared using treatments that enhance destruction of pathogenic bacteria. J. Food Quality, 29:47-64.

Fleuriet A, Macheix JJ (2003). Phenolic acids in fruits and vegetables. In CA Rice-Evans \& L Packer (Eds.), Flavonoids in health and disease. Marcel Dekker Inc.

Hofman PJ, Smith LG, Holmes R, Campbell T, Meiburg G (1995). Mango fruit quality at harvest is affected by production conditions. In: Proceedings of Mango 2000 marketing seminar and production workshop. Brisbane, Australia, pp.199-208.

Hofman PJ, Smith LG, Joyce DC, Johnson GI, Meiburg G (1997). Bagging of mango (Mangifera indica cv. 'Keitt') fruit influences fruit quality and mineral composition. Postharvest Biol. Technol. 12:83-91.

Jacobi KK, Wong LS, Giles JE (1995). Effect of fruit maturity on quality and physiology of high-humidity hot air-treated 'Kensington' mango (Mangifera indica Linn.). Postharvest Biol. Technol. 5:149-159.

Kaur M, Singh N, Sandhu KS, Guraya HS (2004). Physicochemical, morphological, thermal and rheological properties of starches separated from kernels of some Indian mango cultivars (Mangifera indica L.). Food Chem. 85:131-140.

Khalid R (2007). Studies on free radicals, antioxidants, and co-factors. Clin. Interv. Aging. 2:219-236.

Kim H, Moon JY, Kim H, Lee DS, Cho M, Choi HK, Kim YS, Mosaddik A, Cho SK (2010). Antioxidant and antiproliferative activities of mango (Mangifera indica L.) flesh and peel. Food Chem. 121:429436.

Kim Y, Brecht JK, Talcot ST (2007). Antioxidant phytochemical and fruit quality changes in mango following hot water immersion and controlled atmosphere storage. Food Chem. 105:1327-1334.

Lakshminarayana S, Subhadra N, Subramanyam H (1979). Some aspects of developmental physiology of the mango fruit. J. Hort. Sci. 45:133-142.

Lalel HJD, Singh Z, Tan SC (2003). Maturity stage at harvest affects fruit ripening, quality and biosynthesis of aroma volatile compounds in 'Kensington Pride' mango. J. Hort. Sci. Biotechnol. 78:225-233.

Larrauri JA, Ruperez P, Borroto B, Saura-Calixto F (1996). Mango peel as a new tropical fiber: preparation and characterization. Trends in Food Sci. Technol. 329:729-733.

Léchaudel M, Joas J (2006). Quality and maturation of mango fruits of Cv. Cogshall in relation to harvest date and carbon supply. Austr. J. Agric. Res. 57:419-426.

Lim YY, Lim TT, Tee JJ (2007). Antioxidant properties of several tropical fruits: A comparative study. Food Chem. 103:1003-1008.

Lizada MC (1991). Postharvest physiology of the mangos-A review. Acta Hortic. 291:437-453.

Loelillet D (1994). The European mango market: A promising tropical fruit. Fruit 49:332-334.

Meneses M, Guamán M, Adami R, Scognamiglio M, Caputo G, Reverchon E. (2013). Supercritical antisolvent fractionation of bio- active compounds from mango by-products. III Iberoamerican Conference on Supercritical Fluids Cartagena de Indias (Colombia), 1-7.

Mercandate AZ, Rodriguez-Amaya DB (1998). Effects of ripening, cultivar difference and processing on the carotenoids composition of mango. J. Agric. Food Chem. 48:128-130.

Min SY, Yang H, Seo SG, Shin SH, Chung MY, Kim J, Lee SJ, Lee HJ, Lee KW (2013). Cocoa polyphenols suppress adipogenesis in vitro and obesity in vivo by targeting insulin receptor. Inter. J. Obesity. 37:584-592.

Mitra SK (1997). Postharvest physiology and storage of tropical and subtropical fruits, CAB International, Wallingford, Oxon, OX10 8DE, UK.

Moharram YG, Moustafa AM (1982). Utilisation of mango seed kernel (Mangifera indica) as a source of oil. Food Chem. 8:269-276.

Mudau FN, Mabusela PJ, Ngezimana W (2013). Proximate, chemical compositions and sulphur concentrations on quality of selected dried mango (Mangifera indica L.). Afr. J. Biotechnol. 12:2678-2684.

Muoki PN, Makokha AO, Onyango CA, Ojijo NK (2009). Potential contribution of mangoes to reduction of vitamin A deficiency in Kenya. Ecol. Food Nutr. 48:482-498.

Noratto GD, Bertoldi MC, Krenek K, Talcott ST, Stringheta PC, MertensTalcott SU (2010). Anticarcinogenic effects of polyphenolics from mango (Mangifera indica) varieties. J. Agric. Food Chem. 58:41044112.

Nunes CN, Emond JP, Brecht JK, Dea S, Proulx E (2007). Quality curves for mango fruit (cv. Tommy Atkins and Palmer) stored at chilling and nonchilling temperatures. J. Food Qual. 30:104-120.

Ojokoh AO (2007). Effect of fermentation on the chemical composition of mango (Mangifera indica R) peels. Afr. J. Biotechnol. 6:1979-1981.

Othman OC, Mbogo GP (2009). Physico-chemical characteristics of storage-ripened mango (Mangifera indica L.) fruits varieties of eastern Tanzania. Tanz. J. Sci. 35:57-66.

Palmeira SMV, Gois LM, Souza LD (2012). Extraction of phenolic compounds from mango peels. Latin American App. Res.42:77-81.

Parr AJ, Bolwell JP (2000). Phenols in the plant and in man. The potential for possible nutritional enhancement of the diet by modifying the phenol content or profile. J. Food Sci. Agric. 80:985-1012.

Pedroza-Islas R, Aguilar-Esperanza E (1994). Obtaining pectins from solid wastes derived from mango processing. AIChE Symposium Series 300:36-41.

Pietta PG (2000). Flavonoids and antioxidants. J. Nat. Prod. 63:10351042.

Puravankara D, Bohgra V, Sharma RS (2000). Effect of antioxidant principles isolated from mango seed kernels on oxidative stability of buffalo ghee (buffer fat). J. Food Sci. Agric. 80:522-526.

Ravindran V, Sivakanesan R (1996). The nutritive value of mango seed kernels for starting chicks. J. Sci. Food Agric. 71:245-250.

Reyers TT, Vega WF (1988). Factors involved in storage of many fruits: A new evaluation proceedings International Society Citriculture. pp 227-231.

Rodríguez Pleguezuelo CR, Durán Zuazo VH, Muriel Fernández JL, Franco Tarifa D (2012). Physico-chemical quality parameters of mango (Mangifera indica L.) fruits grown in a Mediterranean subtropical climate (SE Spain). J. Agr. Sci. Tech. 14: 365-374.

Saikat S, Chakraborty CS, Reddy YSR, Biplab De (2010). Free radicals, antioxidants, diseases and phytomedicines: Current status and future prospect. Inter. J Pharmaceutical Sci. Rev. Res. 3:91-100.

Schieber A, Ullrich W, Carle R (2000). Characterization of polyphenols in mango puree concentrates by HPLC with diode array and mass spectrometric detection. Innov. Food Sci. Emerging Tech. 1:161-166.

Souza IG, Valente SE, Britto FB, de Souza VA, Lima PS (2011). RAPD analysis of the genetic diversity of mango (Mangifera indica) germplasm in Brazil. Genet. Mol. Res. 10:3080-3089.

Srirangarajan AN, Shrikhande AJ (1976). Mango peel waste as a source of pectin. Current Sci. 45:620-621.

Statistical analysis system institute Inc. (1999). User's guide, Version 8.0. 2nd ed. Vol.2, Cary NC, USA.

Tahir FM, Pervaz MA, Hameed C (2002). Losses of mango fruits after harvest and its control. Agri. Digest, 37: 62-64.

Taing MW, Pierson JT, Hoang VL, Shaw PN, Dietzgen RG, Gidley MJ, Roberts-Thomson SJ, Monteith GR (2012). Mango fruit peel and 
flesh extracts affect adipogenesis in 3T3-L1 cells. Food Funct. 3:828836.

Taing MW, Pierson JT, Shaw PN, Dietzgen RG, Roberts-Thomson SJ, Gidley MJ, Monteith GR (2013). Mango (Mangifera indica L.) peel extract fractions from different cultivars differentially affect lipid accumulation in 3T3-L1 adipocyte cells. Food Func. 3:481-491.

Tandon DK, Garg N (1999). Mango waste: a potential source of pectin fiber and starch. Indian J. Environ. Protection. 19:924-927.

Tandon DK, Kalrat SK, Singh BP, Garg N (1991). Characterization of pectin from mango fruit waste. Indian Food Packer 45:9-12.

Tomas-Barberan F, Espín JC (2001). Phenolic compounds and related enzymes as determinants of quality in fruits and vegetables. J. Food Sci. Agric. 81:853-876

Ueda M, Sasaki KS, Utsunimiya N, Inaba K, Bayashi YS (2000). Variation of total polyphenol oxidase activity during maturation of mango fruit (Mangifera indica L. Irwin) cultured in plastic greenhouse. Food Sci. Tech. Res. 6:299-305.
Van Duyn MA, Pivonka E (2000). Overview of the health benefits of fruit and vegetable consumption for the dietetics professional. Selected literature. JADA 12:1511.

Wang CZ, Sangeeta M, Tyler C, Yuan CS (2011). Botanical Flavonoids on Coronary Heart Disease. Am J Chin Med. 4:661-671

Waterman PG, Mole S (1994). Analysis of phenolic plants metabolites. Oxford Blackwell Scientific Publications. London.

Wolfe K, Wu X, Liu RH (2003). Antioxidant activity of apple peels. J. Agric. Food Chem.51:609-614. 